\title{
Prevalence of Errors and Number of Retakes in Panoramic Radiography: Influence of Professional Training and Patient Characteristics
}

\author{
Prevalencia de Errores y Número de Repeticiones en Radiografía Panorámica: \\ Influencia de la Formación Profesional y las Características de los Pacientes
}

\author{
Eliana Dantas Costa'; Wilson Gustavo Cral'; Fernanda Pinto Murad'; Matheus Lima \\ Oliveira1; Glaucia Maria Bovi Ambrosano² \& Deborah Queiroz Freitas ${ }^{1}$
}

COSTA, E. D.; CRAL, W. G.; MURAD, F. P.; OLIVEIRA, M. L.; AMBROSANO, G. M. B. \& FREITAS, D. Q. Prevalence of errors and number of retakes in panoramic radiography: Influence of professional training and patient characteristics. Int. $J$. Odontostomat., 15(3):719-726, 2021.

\begin{abstract}
Panoramic radiography has clinical importance in several dental specialties. The objective of this study was to evaluate the influence of professionals' experience and patient characteristics (age group and dental absence) in the prevalence of errors and the number of retakes in the panoramic radiography. 771 panoramic radiographs were evaluated and classified according to the group of patients (children, dentulous adults, total edentulous adults, and anterior edentulous adults) and professionals who performed the technique (novice and experienced). The association between frequency and type of error, group of patients, professionals' experience, and number of retakes was performed by the Chi-square and Fisher's exact test $(a=0.05)$. There was no significant association between the frequency of errors or retakes of the radiographs and the professionals' experience or patients' characteristics $(p<0.05)$. The errors "turned head" and "tongue not against the palate," "chin tipped low", "chin not resting on the support," "patient movement during exposure," and "lead apron artifact" showed significantly higher frequency of retake $(p<0.05)$. The most frequent type of error was due to the failure to position the tongue against the palate for all patients and both groups of professionals. The frequency of errors in the panoramic radiography occurs regardless of the professionals' experience, and age and dental absence of the patients. Error occurs mainly due to the lack of patient collaboration, and the examination is rarely repeated by the professionals.
\end{abstract}

KEY WORDS: radiography; diagnosis; radiology.

\section{INTRODUCCIÓN}

The panoramic radiography has clinical importance in several dental specialties (Ramos et al., 2016), since it allows professionals to comprehensively visualize the dental arches and hard tissues of the maxillofacial region in a single image (Granlund et al., 2012; Devlin \& Yuan, 2013; Ekströmer \& Hjalmarsson, 2014; Suomalainen et al., 2015). In this radiographic technique, the two-dimensional projection of the curved structures of the jaws can be observed, due to the reciprocal movement of the $X$-ray source and the image receptor following a center of rotation that continuously moves according to the shape of the jaws (Langland \& Langlais, 2002; Boeddinghaus \& White, 2006; Ramos et al.). During this movement, a three-dimensional curved focal plane (image layer) is created, similar to the dental arch (Langland \& Langlais; Akarslan et al., 2003; Ramos et al.), and only objects positioned in this region are sharp. In this sense, to ensure that all regions of interest appear in the image, the correct positioning of the patient is important (Boeddinghaus \& White; Dhillon et al., 2012; Ekströmer \& Hjalmarsson; Rondon et al., 2014).

\footnotetext{
${ }^{1}$ Division of Oral Radiology, Department of Oral Diagnosis, Piracicaba Dental School, University of Campinas, Piracicaba, SP, Brazil.

${ }^{2}$ Department of Community Dentistry, Piracicaba Dental School, University of Campinas, Piracicaba, SP, Brazil.
} 
Thus, to correctly guide the professional when positioning the patient in the focal plane, panoramic units are equipped with a bite block and laser lights, as well as devices for stabilizing the patients' heads during the exposure (Akarslan et al.; Boeddinghaus \& White; Devlin \& Yuan; Ekströmer \& Hjalmarsson). However, the lack of experience of the professional (Boeddinghaus \& White; Granlund et al.; Dhillon et al.; Ekströmer \& Hjalmarsson), the age of the patients, and the presence of anatomical differences, such as short neck, overweight, facial asymmetries, and dental absence, may influence the correct positioning (Akarslan et al.; Peretz et al., 2012; Dhillon et al.; Ekströmer \& Hjalmarsson). In addition, errors related to the lack of patients' cooperation may occur (Granlund et al.; Dhillon et al.; Ekströmer \& Hjalmarsson; Cordesmeyer et al., 2016).

In such situations, it is important for professionals to know how to recognize errors and the need for retake (Loughlin et al., 2017). Several studies have shown that the difficulty of positioning in panoramic radiography cannot be underestimated (Granlund et al.; Dhillon et al.; Ekströmer \& Hjalmarsson; Rondon et al.; Loughlin et al.). However, to the authors' knowledge, there is a gap in the literature regarding the frequency of errors in patients of different age groups and with dental absences, which could be factors that compromise the correct performance of the technique.

Thus, our aim was to evaluate the influence of professionals' experience and patients' characteristics (age group and dental absence) in the prevalence of errors and the number of retakes in the panoramic radiography.

\section{MATERIAL AND METHOD}

The study was approved by the local Research Ethics Committee (CAAE: 93632518.4.0000.5418).

Sample. The sample consisted of 771 panoramic radiographs, randomly selected from the Oral Radiology clinic of our Dental School. This sample was obtained by sample size with $a<4 \%$ estimation of sample error and test power above $80 \%$ in tests regarding the association between error in the panoramic radiography and patients' age and professionals' experience.
Images with insufficient sharpness and/or contrast were excluded from the study. All of them were obtained from either the OP100 or OP300 unit (Instrumentarium Dental, Tuusula, Finland) with exposure factors selected according to the patients' characteristics by the professional, who were categorized into two levels of experience of clinical practice in oral radiology: novice (1 to 2 years) or experienced ( 3 to 6 years). In this study, all of the professionals were dental practitioners pursuing their postgraduate degree (Master's or PhD).

Panoramic images were classified according to the level of experience of the professional, the type of error and the following groups of patients according to their age and dental presence/ absence:

1. Children: patients aging up to 12 years;

2. Total edentulous adults: total edentulous patients; 3. Partial edentulous adults (in the anterior region): patients with absence of the upper and/or lower incisors, which makes impossible the use of the bite block;

4. Dentulous adults: patients older than 12 years, who did not fit into groups 2 and 3 .

Image Assessment. The panoramic radiographs were exported in TIFF format and evaluated by consensus by two oral radiologists in a 24-inch high-resolution LCD monitor (MDRC 2124, Barco Inc., Duluth, GA) under low light conditions using the JPEG View software, who had to detect and classify technique-related errors according to Langland \& Langlais. Zoom, brightness, and contrast tools could be used. When a consensus was not reached, a third evaluator assisted in the decision. Figures 1 and 2 show some errors with need or not for retake.

Data Analysis. Tables containing the distribution, and absolute and relative frequencies of the types of error, professionals' experience, and group of patients were compiled. The association between the professionals' experience (novice or experienced), group of patients (children, dentulous adults, total or partial edentulous adults), frequency and type of error, and number of retakes was tested by Chi-Square and Fisher's exact tests. For all analyses, a significance level of $5 \%(a=0.05)$ was considered. Statistical analyses were performed by the $S A S \otimes$ software v. 9.2 (SAS Institute Inc., Cary, NC). 


\section{RESULTS}

Of the total radiographs, $246(31.9 \%)$ were performed by novice professionals and $525(68.1 \%)$ by experienced professionals, being $86(11.1 \%)$ radiographs of children, $573(74.3 \%)$ of dentulous adults, $46(6.0 \%)$ of edentulous adults, and $66(8.6 \%)$ of partial edentulous adults (anterior region). The frequency of radiographs containing errors was similar for novice $(68.7 \%)$ and experienced $(69.1 \%)$ professionals; however, $72.8 \%$ of the novice professionals and $65.6 \%$ of the experienced professionals did not retake the radiographs containing errors. Of the 532 radiographs with errors, only 171 $(32.1 \%)$ were repeated.

Table I. Absolute and relative number of panoramic radiographs containing errors and retakes, according to the professionals' experience and patients' age and dental absence).

\begin{tabular}{|c|c|c|c|c|c|}
\hline & \multirow{2}{*}{ Patient groups } & \multirow{2}{*}{ Total Patients } & \multicolumn{2}{|c|}{ Professionals' experience } & \multirow{2}{*}{$\begin{array}{c}p \text {-value } \\
\text { (professional } \\
\text { education) }\end{array}$} \\
\hline & & & Novice & Experienced & \\
\hline \multirow[t]{5}{*}{ Radiograph containing errors } & Children & $59(11.1)$ & $13(7.7)$ & $46(12.7)$ & 0.9012 \\
\hline & Adults & $391(73.5)$ & $132(78.1)$ & $259(71.3)$ & \\
\hline & Edentulous & $31(5.8)$ & $10(5.9)$ & $21(5.8)$ & \\
\hline & Partial & $51(9.6)$ & $14(8.3)$ & $37(10.2)$ & \\
\hline & Total & $532(100.0)$ & $169(100.0)$ & $363(100.0)$ & \\
\hline$p$-value (patient group) & & 0.5069 & 0.1335 & 0.4107 & \\
\hline \multirow{5}{*}{$\begin{array}{l}\text { Retake of radiographs } \\
\text { containing errors }\end{array}$} & Children & $19(11.1)$ & $3(6.5)$ & $16(12.8)$ & 0.2261 \\
\hline & Adults & $127(74.3)$ & $34(73.9)$ & $93(74.4)$ & \\
\hline & Edentulous & $10(5.8)$ & $5(10.9)$ & $5(4.0)$ & \\
\hline & Partial & $15(8.8)$ & $4(8.7)$ & $11(8.8)$ & \\
\hline & Total & $171(100.0)$ & $46(100.0)$ & $125(100.0)$ & \\
\hline$p$-value (patient group) & & 0.6283 & 0.1588 & 0.2799 & \\
\hline
\end{tabular}
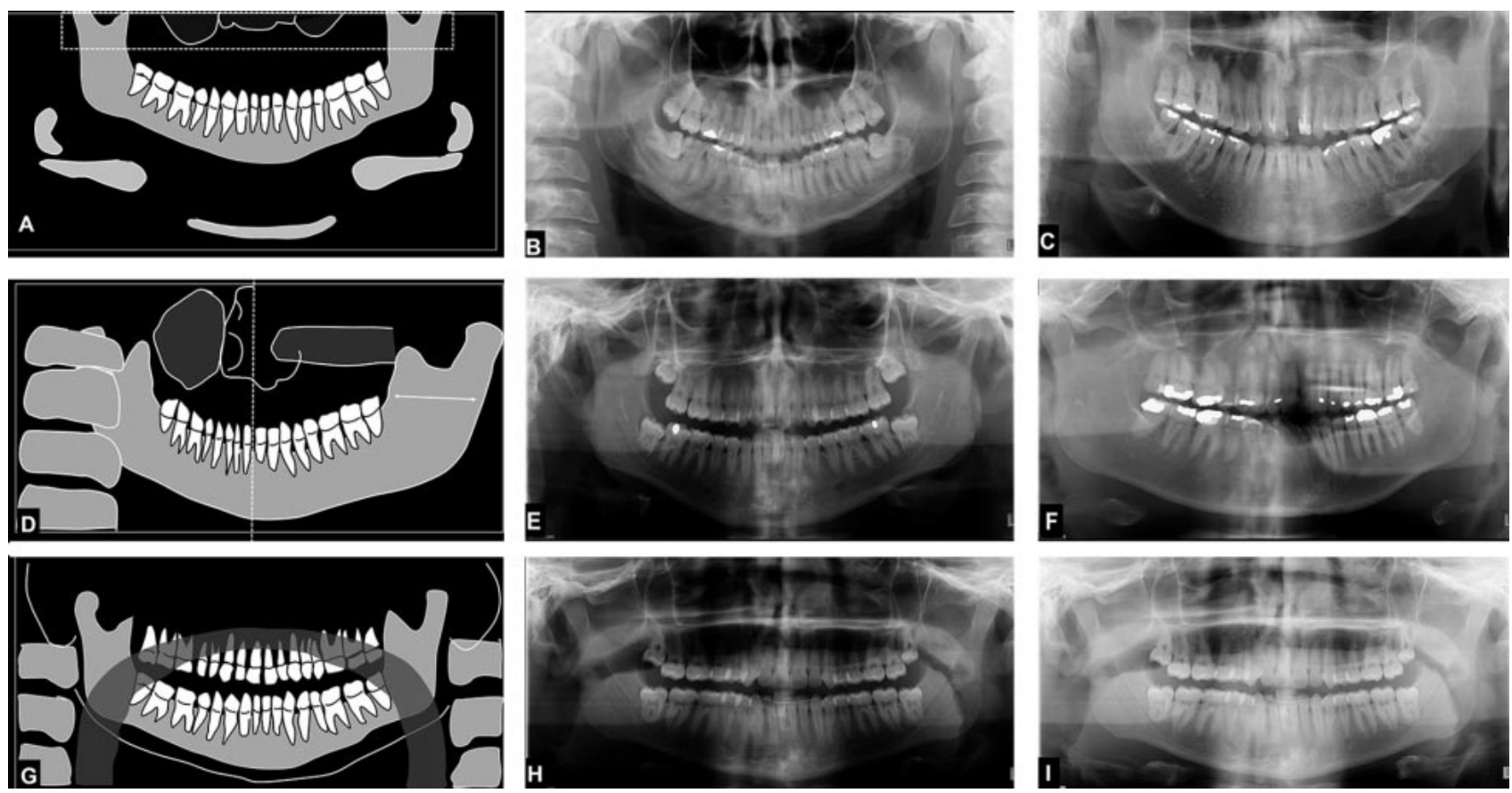

Fig. 1. A, D and G - Schematic drawing of positioning errors (adapted from Langland \& Langlais, 2002). A, B, and C - Error type "chin not resting on the chin support." D, E, and F - Error type "turned head". E - Left side of the patient was slightly magnified. F - Patient with accentuated asymmetry between the right and left sides; right side of the patient was magnified. $\mathrm{G}$ and $\mathrm{H}$ - Radiolucent image in the apices of the upper teeth, corresponding to the "failure to position the tongue against the palate." I - The adjustment of brightness and contrast of Figure $\mathrm{H}$ allows the visualization of the apices of the upper teeth. 
In general, without considering the type of error, no significant association was observed between the frequency of errors or retakes and the experience of the professional or group of patients $(p<0.05)$ (Table I).

Considering the group of patients, a significant association was observed $(p<0.05)$ between the error "patient positioned forward the bite block" and partial edentulous adult patients; "slumped position" and total edentulous adult patients; and "patient movement during exposure" and children (Table II).

Considering the level of experience of the professional who performed the technique, novice professionals presented significantly higher frequency of the error "chin tipped low" $(p<0.05)$ (Table II).

The errors "turned head", "chin tipped low", "chin not appropriately resting on the support", "tongue not against the palate", "patient movement during exposure", and "lead apron artifact" presented significant association with the number of retakes of the radiographs $(p<0.05)$ (Table II). For the error "chin not appropriately resting on the support", the highest frequency was one retake (Table II and Figs. 1A, B, and C). For the errors "turned head" (Fig. 1D, E, and F) and "tongue not against the palate" (Figs. 1G, $\mathrm{H}$, and $\mathrm{I}$ ), the need for two retakes was more frequent (Table II). For the errors "chin tipped low" (Figs. 2A, B, and C), "patient movement during exposure" (Figs. 2D, E, and F), and "lead apron artifact" (Figs. 2G, H, and I), the highest frequency was for three retakes (Table II).

The error "tongue not against the palate" was the most frequent regardless of the age group and the experience of the professional, and, for children, adults, and partial edentulous, the frequency was higher than $70.0 \%, 40.0 \%$, and $50.0 \%$, respectively (Table III) for both groups of professionals. Conversely, for the total edentulous group, the frequency of this error was $70.0 \%$ for novice, and $38.1 \%$ for experienced professional students (Table III).

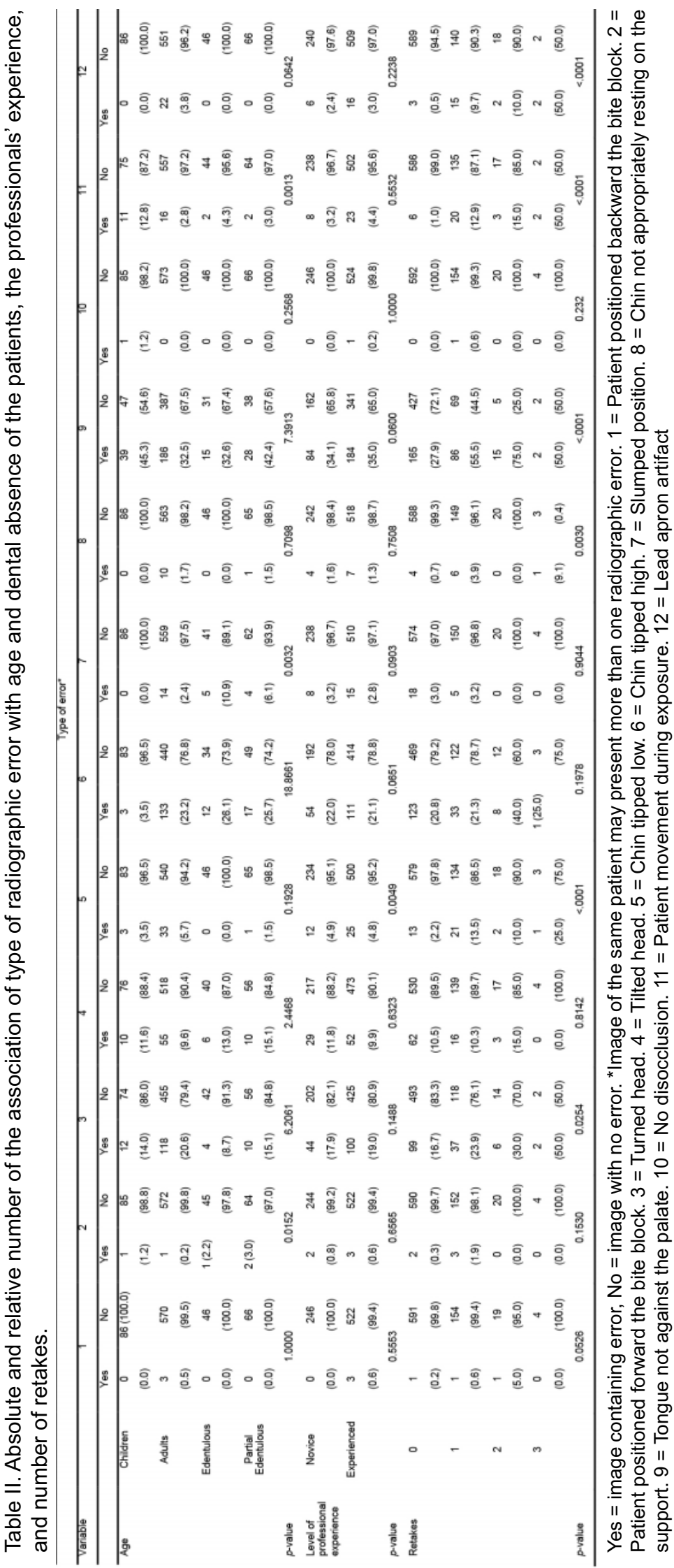




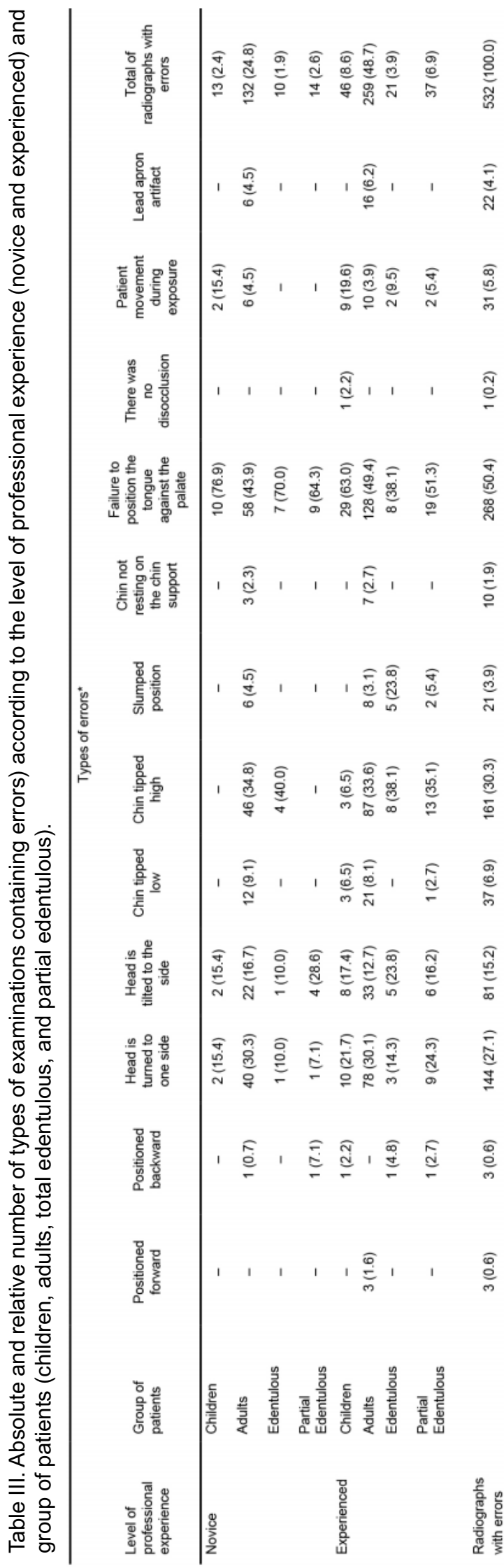

\section{DISCUSSION}

Panoramic radiography is a technique sensitive to errors (Granlund et al.; Dhillon et al.; Ekströmer \& Hjalmarsson; Rondon et al.; Loughlin et al.), which may hinder, limit, or impair the diagnostic value of the resulting images (Ekströmer \& Hjalmarsson). Thus, it is important to evaluate the prevalence of errors of such a widely used technique in dentistry, in addition to the need for retake, as a way of contributing to better training of the professional team.

Overall, there was no significant association between the frequency of errors or retakes of the panoramic radiographs and both the professionals' experience and the group of patients.

The experience of the professional was one of the studied factors, since we expected that a longer period of clinical practice in oral radiology would result in less errors. However, although all the professionals of our study received the same training concerning theexecution of the technique, previous clinical experience may have been different within the same group of professionals' experience, and could explain the lack of association between the frequency of errors and the level of the experience of the professionals.

Although we observed high frequency of radiographs containing errors (approximately $70 \%$ ), this is reduced in relation to previous studies, in which authors showed a frequency equal to or greater than 90 \% (Granlund et al.; Dhillon et al.; Ekströmer \& Hjalmarsson). This probably occurred because all the professionals of the present study underwent an intense training period before performing the technique. Hence, it is suggested that the training received is a fundamental factor to ensure the quality of the radiograph (Rondon et al.; Loughlin et al.). Corroborating these findings, authors of a previous study (Akarslan et al.) observed that $62.4 \%$ of the radiographs presented errors because they were performed by radiology technicians with 2.5 to 3 years of experience.

For the group of patients, children may have more difficulty in standing still during the radiographic acquisition (from 13 to 20 seconds) (Peretz et al.; Ekströmer \& Hjalmarsson), thus justifying the higher frequency of movements. By 

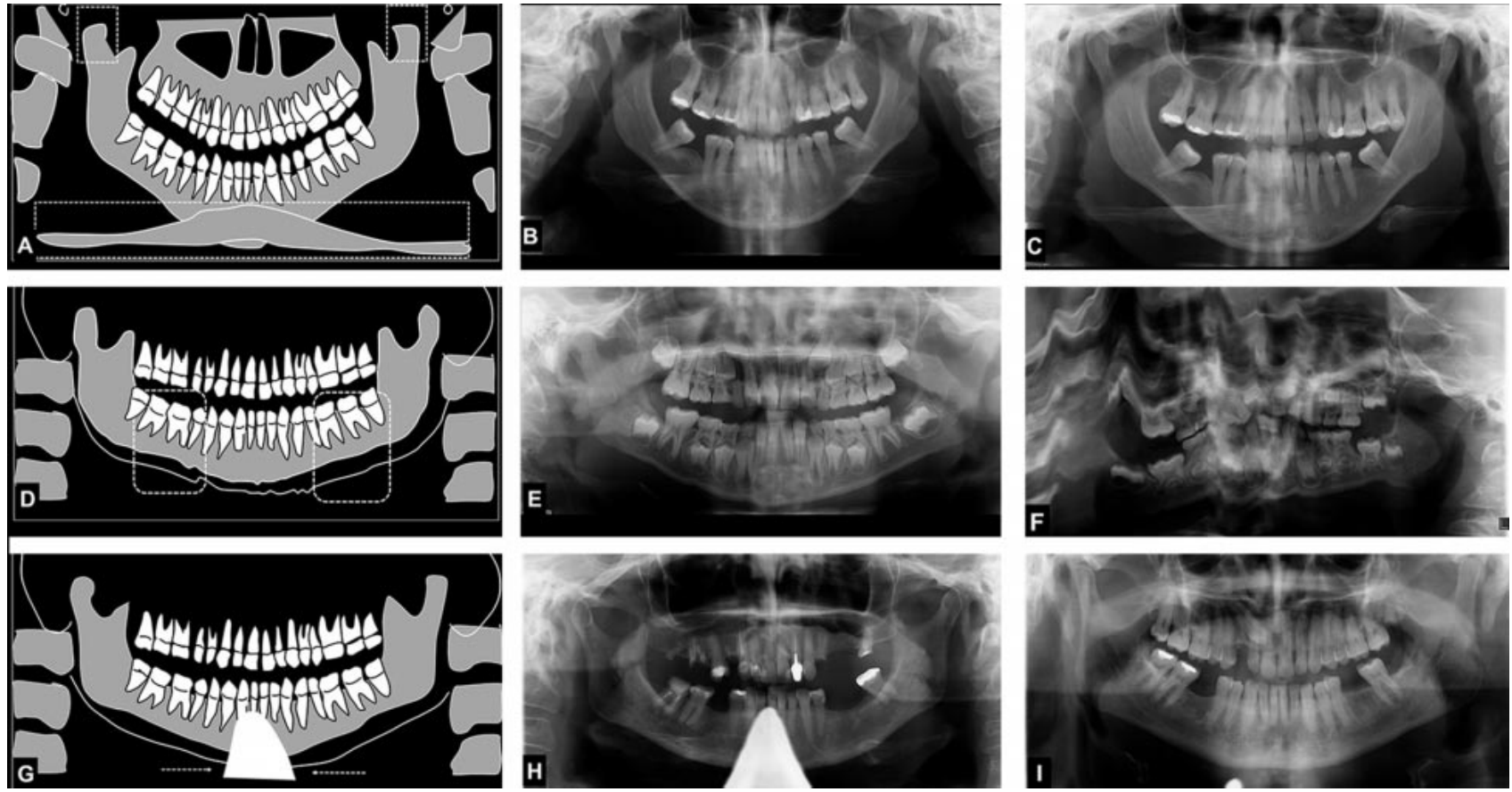

Fig. 2. A, D and G - Schematic drawing of positioning errors (adapted from Langland \& Langlais, 2002); dashed areas and arrows indicate region altered in the image. A and B - Error type "chin tipped low." C - Retake the radiograph of Figure B. D, E, and F - Error type "patient movement during exposure." $\mathrm{E}$ - Note the distorted image of the base of mandible on the right side, but without need for retake. F - Impairment of the image due to movement artifacts, requiring retake. G, H, and I - Error type "lead apron artifact." H - Images of the lead apron superimposed on the base of the mandible and anterior teeth, requiring retake. I - Image of the lead apron does not interfere in the anatomical structures of the image, without need for retake.

evaluating the group of adult patients, we observed higher frequency for the error "patient positioned forward the bite block" for partial edentulous patients, probably due to greater difficulty in positioning these patients by the absence of anterior teeth. In those cases, a support for the chin is used for the positioning of the patient, which provides lower intermaxillary stability than the bite block for dentulous patients (Park et al., 2014).

Moreover, we verified higher frequency for the type of error "slumped position" for total edentulous patients. Since they are total edentulous, we may infer that these patients were possibly older adults, and thus this error was due to postural problems. The pronounced radiopaque projection in the anterior region of the panoramic radiographs due to postural problems of the cervical spine usually occurs in patients with reduced neck resulting from aging or obesity.

Despite the high frequency of errors, we noticed that not all the radiographs containing them were retaken. This is probably due to the fact that, prior to the performance of a new radiograph, the evaluation of the diagnostic value of the image and the indication of the exam should be taken into account. There was no difference in the number of retakes in relation to the group of professionals' experience, demonstrating a critical sense of radioprotection even for beginners. For the error "chin not appropriately resting on the support" retakes were observed when the image of the condyles was partial (Fig. 1C), which did not occur when these structures appeared in the image (Fig. 1B), although the patient was not ideally positioned.

During the examination, the patient can turn the head, trying to follow the movement of the device (Ekströmer \& Hjalmarsson). In these cases, the resulting image may be asymmetric between the right and left sides (Rondon et al.) with enlargement of the structures distant of the receptor and narrowing of the structures on the contralateral side (Loughlin et al.). However, this error may not affect the quality of the image, if the turn is mild (Fig. 1E), but there is need for retake when the image is severely asymetrical (Fig. $1 \mathrm{~F})$. Moreover, it is important for professionals to assess whether asymmetries in the image are due to patients' anatomical variations; if only some bone structure is asymmetric is probably due to patient's asymmetry; however, if bone and dental structures are asymmetric, there is error during the radiograph acquisition. 
The image resulting from patients that do not place the tongue against the palate can generate a radiolucent band at the apex of the anterior upper teeth (Granlund et al.; Dhillon et al.; Cordesmeyer et al.; Loughlin et al.), which may be mild or more pronounced, preventing the evaluation of this region. Nevertheless, in some cases, with the use of digital systems, the adjustment of brightness and contrast may be beneficial (Figs. 1H and I) (Ekströmer \& Hjalmarsson). However, when even with the use of these image enhancement tools a good visualization of the region is not possible, retakes are required. It is noteworthy that authors of several studies indicate that this type of error is very common (Granlund et al.; Dhillon et al.; Ekströmer \& Hjalmarsson; Cordesmeyer et al.; Loughlin et al.) because it depends on the way the instruction is received and applied by the patients (Akarslan et al.; Dhillon et al.; Ekströmer \& Hjalmarsson; Cordesmeyer et al.). Therefore, for better understanding of patients, reinforcements can be carried out through informative leaflets, self-demonstration of positioning by professionals, or even the use of strategies such as requesting the patient to keep a cotton against the palate with the tongue.

Thus, periodic monitoring of the occurrence of errors is important to verify the need for educational practices and to recycle the knowledge of professionals, aiming at improving the image quality (Peretz et al.; Dhillon et al.). In our study, despite the high frequency of errors, most of them were related to the patient (tongue not against the palate) instead of the professional who performed the radiograph, demonstrating that the instructions transmitted during patient positioning are important (Rondon et al.; Loughlin et al.). In addition, the occurrence of few retakes indicate that the professionals were aware of the errors and repeated the radiographs only when the error interfered in the diagnosis.

\section{CONCLUSION}

The frequency of errors in panoramic radiography occurs regardless of the professionals' experience, and patients' age and dental conditions. Error occurs mainly due to the lack of patients' collaboration, and the most common error is failure to position the tongue against the palate. Despite the high frequency of technical errors, the examination is rarely retaken due to the remaining possibility of image evaluation and diagnosis.

\section{ACKNOWLEDGMENTS}

The authors thank the Coordination for the Improvement of Higher Education Personnel (CAPES) - Finance Code 001, and the National Council for Scientific and Technological Development (CNPq) for the financial support, and the Espaço da Escrita (Writing Center) at the University of Campinas (UNICAMP) for the language services provided.

COSTA, E. D.; CRAL, W. G.; MURAD, F. P.; OLIVEIRA, M. L.; AMBROSANO, G. M. B. \& FREITAS, D. Q. Prevalencia de errores y número de repeticiones en radiografía panorámica: influencia de la formación profesional y las características de los pacientes. Int. J. Odontostomat., 15(3):719-726, 2021

RESUMEN: La radiografía panorámica es de importancia clínica en varias especialidades dentales. El objetivo de este estudio fue evaluar la experiencia de los profesionales y las características de los pacientes (grupo etario y ausencia dentaria) en la prevalencia de errores y el número de repeticiones en la radiografía panorámica. 771 radiografías panorámicas fueron evaluadas y clasificadas según la grupo de pacientes (niños, adultos desdentados, adultos desdentados totales y adultos desdentados anteriores) y profesionales que realizaron la técnica (novatos y experimentados). La asociación entre frecuencia y tipo de error, grupo de pacientes, experiencia de los profesionales y número de repeticiones se realizó mediante la prueba de Chi-cuadrado y exacta de Fisher $(a=0,05)$. No hubo asociación significativa entre la frecuencia de errores o repetición de las radiografías y la experiencia de los profesionales o las características de los pacientes ( $p$ $<0,05)$. Los errores "cabeza girada" y "lengua no contra el paladar", "mentón inclinado hacia abajo", "mentón no apoyado en el soporte", "movimiento del paciente durante la exposición" y "artefacto del delantal de plomo" mostraron una frecuencia de repetición significativamente mayor $(p<0,05)$. El error más frecuente se debió a la falta de posicionamiento de la lengua contra el paladar para todos los pacientes y en ambos grupos de profesionales. La frecuencia de errores en la radiografía panorámica ocurre independientemente de la experiencia de los profesionales, edad y ausencia dentaria del pacientes. El error se produce principalmente por la falta de colaboración del paciente, y los profesionales rara vez repiten el examen.

PALABRAS CLAVE: radiografía, diagnóstico, radiología.

\section{REFERENCES}

Akarslan, Z. Z.; Erten, H.; Güngör, K. \& Celik, I. Common errors on panoramic radiographs taken in a dental school. J. Contemp. Dent. Pract., 4(2):24-34, 2003. 
COSTA, E. D.; CRAL, W. G.; MURAD, F. P.; OLIVEIRA, M. L.; AMBROSANO, G. M. B. \& FREITAS, D. Q. Prevalence of errors and number of retakes in panoramic radiography: Influence of professional training and patient characteristics. Int. J. Odontostomat., 15(3):719-726, 2021

Boeddinghaus, R. \& Whyte, A. Dental panoramic tomography: an approach for the general radiologist. Australas. Radiol., 50(6):526-33, 2006.

Cordesmeyer, R.; Engelke, W.; Sömmer, C. \& Kauffmann, P. Can tongue shadow in panoramic radiographs be avoided by using the tongue repositioning maneuver? Oral Surg. Oral Med. Oral Pathol. Oral Radiol., 121(6):e175-80, 2016.

Devlin, H. \& Yuan, J. Object position and image magnification in dental panoramic radiography: a theoretical analysis. Dentomaxillofac. Radiol., 42(1):29951683, 2013.

Dhillon, M.; Raju, S. M.; Verma, S.; Tomar, D.; Mohan, R. S.; Lakhanpal, M. \& Krishnamoorthy, B. Positioning errors and quality assessment in panoramic radiography. Imaging Sci. Dent., 42(4):207-12, 2012.

Ekströmer, K. \& Hjalmarsson, L. Positioning errors in panoramic images in general dentistry in Sörmland County, Sweden. Swed. Dent. J., 38(1):31-8, 2014.

Granlund, C. M.; Lith, A.; Molander, B.; Gröndahl, K.; Hansen, K. \& Ekestubbe, A. Frequency of errors and pathology in panoramic images of young orthodontic patients. Eur. J. Orthod., 34(4):4527, 2012.

Langland, O. E. \& Langlais, R. P. Principles of Eental Imaging. São Paulo, Editora Santos, 2002.

Loughlin, A.; Drage, N.; Greenall, C. \& Farnell, D. J. J. An investigation in to the impact of acquisition location on error type and rate when undertaking panoramic radiography. Radiography (Lond.), 23(4):305-9, 2017.

Park, J. W.; Huh, K. H.; Yi, W. J.; Heo, M. S.; Lee, S. S. \& Choi, S. C. Comparison of the reproducibility of panoramic radiographs between dentulous and edentulous patients. Imaging Sci. Dent., 44(2):95-102, 2014

Peretz, B.; Gotler, M. \& Kaffe, I. Common errors in digital panoramic radiographs of patients with mixed dentition and patients with permanent dentition. Int. J. Dent., 2012:584138, 2012.

Ramos, B. C.; da Silva Izar, B. R.; Pereira, J. L. C.; Souza, P. S.; Valerio, C. S.; Tuji, F. M. \& Manzi, F. R. Formation of ghost images due to metal objects on the surface of the patient's face: A pictorial essay. Imaging Sci. Dent., 46(1):63-8, 2016.

Rondon, R. H. N.; Pereira, Y. C. L. \& do Nascimento, G. C. Common positioning errors in panoramic radiography: A review. Imaging Sci. Dent., 44(1):1-6, 2014.

Suomalainen, A.; Esmaeili, E. P. \& Robinson, S. Dentomaxillofacial imaging with panoramic views and cone beam CT. Insights Imaging, 6(1):1-16, 2015.
Corresponding author:

Eliana Dantas Costa

Division of Oral Radiology

Department of Oral Diagnosis

School of Dentistry at Piracicaba

University of Campinas

Av. Limeira 901

Areião, Piracicaba

SP. Zip Code 13414-018

BRAZIL

E-mail: edantasc@yahoo.com.br 